\title{
A novel method for heterocyclic amide-thioamide transformations
}

\author{
Walid Fathalla ${ }^{*}$, Ibrahim A. I. Ali ${ }^{2}$ and Pavel Pazdera ${ }^{3}$
}

\author{
Full Research Paper \\ Address: \\ ${ }^{1}$ Physics and Math. Engineering Dept., Faculty of Engineering, \\ Port-Said University, Port Said, Egypt, ${ }^{2}$ Department of Chemistry, \\ Faculty of Science, Suez Canal University, Ismailia, Egypt and \\ ${ }^{3}$ Centre for Syntheses at Sustainable Conditions and Their \\ Management, Faculty of Science, Masaryk University, Brno, Czech \\ Republic \\ Email: \\ Walid Fathalla* - walid3369@yahoo.com \\ * Corresponding author \\ Keywords: \\ heterocyclic amides; heterocyclic thioamides; $\mathrm{N}$-cyclohexyl \\ dithiocarbamate cyclohexylammonium salt; novel thiating agent; \\ thiation
}

Beilstein J. Org. Chem. 2017, 13, 174-181.

doi:10.3762/bjoc. 13.20

Received: 07 October 2016

Accepted: 10 January 2017

Published: 26 January 2017

This article is dedicated to my late dearest professors, Faisal El-Oreeny and Tayseer Abdelrassool.

Associate Editor: B. Stoltz

(C) 2017 Fathalla et al.; licensee Beilstein-Institut.

License and terms: see end of document.

\section{Abstract}

In this paper, we introduce a novel and convenient method for the transformation of heterocyclic amides into heteocyclic thioamides. A two-step approach was applied for this transformation: Firstly, we applied a chlorination of the heterocyclic amides to afford the corresponding chloroheterocycles. Secondly, the chloroherocycles and $N$-cyclohexyl dithiocarbamate cyclohexylammonium salt were heated in chloroform for $12 \mathrm{~h}$ at $61{ }^{\circ} \mathrm{C}$ to afford heteocyclic thioamides in excellent yields.

\section{Introduction}

Transforming heterocyclic amides into thioamides is an important task in organic synthesis. Earlier reports for this type of $\mathrm{O} / \mathrm{S}$ conversions were achieved by several thiating reagents; for instance, Lawesson's reagent (2,4-bis(4-methoxyphenyl)-1,3dithia-2,4-diphosphetane 2,4-disulfide) [1-3], Berzelius reagent [4-6] $\left(\mathrm{P}_{4} \mathrm{~S}_{10}\right)$, and phosphorus pentasulfide [7] in dry toluene, xylene or pyridine under reflux conditions. A two-step approach for the purpose of thiation of heterocyclic amides attracted our attention: as a first step, we applied a chlorination of heterocyclic amides, followed by thiation via reaction with thio- urea on the basis of reagent-promoted desulfurylation of isothiourea under strong basic conditions [8,9]. Aiming to continue our reseach work on the structure modification of functionalized heterocyclic amides and thioamides [10-17], we found it interesting to design a new convenient and simple method for the thiation of heterocyclic amides.

\section{Results and Discussion}

Many synthetic methods related to thiation of heterocyclic amides have been reported to date. Most methods suffer from 
the employment of expensive specific reagents, high temperature, use of strong basic conditions, ultra-dry solvents, bad smell, low yield, difficulties in work-up procedures or from a narrow substrate scope. Therefore, the development of a more efficient method for the transformation of heterocyclic amides to heterocyclic thioamides gained great attention.

The reaction of three molar equivalents of cyclohexylamine (1) with one molar equivalent of carbon disulfide in water typically afforded $N$-cyclohexyl dithiocarbamate cyclohexylammonium salt (2) as an excellent new thiating reagent in high yield, Scheme 1 .

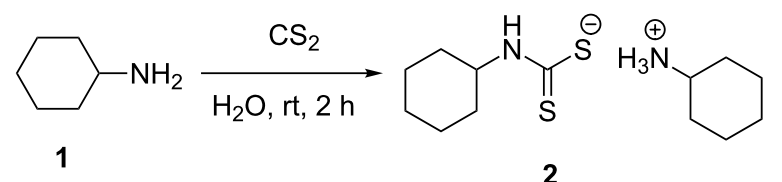

Scheme 1: Synthesis of $N$-cyclohexyl dithiocarbamate cyclohexylammonium salt (2).

The structure assignment of the prepared $N$-cyclohexyl dithiocarbamate cyclohexylammonium salt (2) is based on ${ }^{1} \mathrm{H}$ and ${ }^{13} \mathrm{C}$ NMR spectral and physicochemical analysis. The ${ }^{1} \mathrm{H}$ NMR spectrum displays a broad singlet signal at $8.01 \mathrm{ppm}$ associated with three $\mathrm{NH}$ protons. The ${ }^{1} \mathrm{H}$ NMR spectrum also shows three multiplet signals at 4.15-3.95 and 3.05-2.96 and 1.98-0.96 ppm corresponding to two $\mathrm{CH}$ and $10 \mathrm{CH}_{2}$ groups, respectively. The ${ }^{13} \mathrm{C}$ NMR spectrum of 2 displays signals at $\delta 212.4,55.3$ and $50.0 \mathrm{ppm}$ associated with $(\mathrm{C}=\mathrm{S})$ and two $\mathrm{CH}$ groups, respectively. The ${ }^{13} \mathrm{C}$ NMR spectrum of 2 also shows signals at 32.3, $30.9,25.8,25.5,25.1$, and $24.3 \mathrm{ppm}$ due to cyclohexyl $\mathrm{CH}_{2}$ groups.

Heterocyclic amides A1-13 used in this context were prepared as described in literature expanding simple one-step procedures to multi-step sequential reactions. Quinazoline-4-one (A1) [18] was prepared by Niementowski reaction by fusion of anthranilic acid with formamide at $120{ }^{\circ} \mathrm{C}$ for $5 \mathrm{~h}$. A number of quinazoline derivatives A2-A6 [19-21] were prepared via sequential steps starting from easily available carboxylic acid chlorides. The acid chlorides reacted with anthranilic acid to afford benzoxazines, followed by sequential reaction with ammonia to afford the benzanilide derivatives and finally, benzanilides were cyclized by heating in sodium hydroxide solution and gave quinazolines A2-A6. Methyl 1,2-dihydro-2-oxoquinoline-4carboxylate (A9) [22,23] was prepared by heating isatine with malonic acid followed by esterification of the produced quinoline carboxylic acid with methanol in the presence of sulfuric acid at $80{ }^{\circ} \mathrm{C}$ for 6 h. 4 -Arylphthalazin-1(2H)-ones $\mathbf{A 7}$ and $\mathbf{A 8}$ [24,25] were prepared by Friedel-Crafts acylation reaction of $\mathrm{N}$-aminophthalimide with either benzene or toluene in the presence of $\mathrm{AlCl}_{3}$, respectively. A number of quinoxalin-2-one derivatives A10-13 [26-29] were prepared by the reaction of $o$-phenylenediamine with oxoacids or oxoesters either in $\mathrm{HCl}$ solution or in ethanol.

Heterocyclic amides A1-9 were heated with $\mathrm{POCl}_{3}$ for $2-5 \mathrm{~h}$ as reported in literature to afford the respective chloroheterocycles [30-37] B1-9 and 13 and were purified using flash column chromatography; petroleum ether (60-80)/ethyl acetate (9:1) as an eluent. Best results for the preparation of chloroquinoxalinones B11 and B12 [38,39] were achieved by dropwise addition of $\mathrm{N}, \mathrm{N}$-dimethylaniline to a stirred cold solution of quinoxalinones A11 and A12 and $\mathrm{POCl}_{3}$, the reaction mixture was refluxed for 15 minutes.

Thus, $N$-cyclohexyl dithiocarbamate cyclohexylammonium salt (2) was added to 4-chloro-2-phenylquinazoline (B2) solution in $\mathrm{CHCl}_{3}$, the reaction mixture was heated at $61^{\circ} \mathrm{C}$ for $12 \mathrm{~h}$. The reaction mixture was evaporated and poured in ethanol to give bright yellow crystals as only isolated product, identified as 2-phenylquinazoline-4(3H)-thione (C2). The filtrate was once again evaporated and crystalized from ethanol/water to give dicyclohexylthiourea (3, Scheme 2). We have extended the scope of this process to involve the transformation of a number of heterocyclic amides; quinazolin-4(3H)-one (A1), 2-substituted quinazolin-4(3H)-one A3-A6 and 4-subsituted phthalazin1(2H)-ones A7 and A8 into the corresponding heterocyclic thioamides $\mathbf{C 1}$ and $\mathbf{C 3}-\mathbf{C 8}$, respectively (Scheme 2, Table 1 and Table 2).

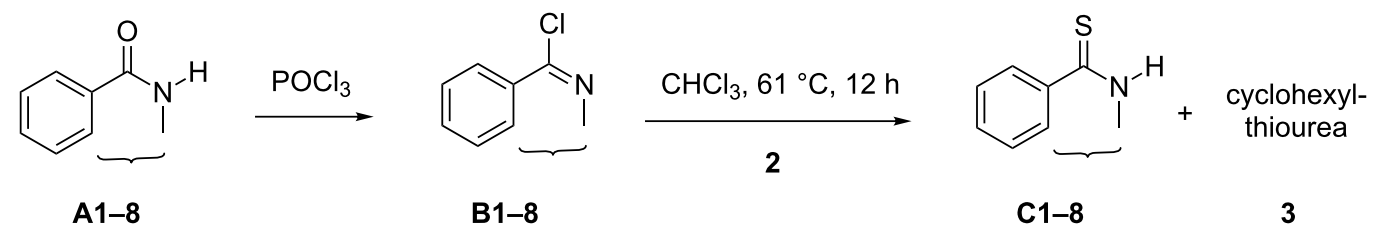




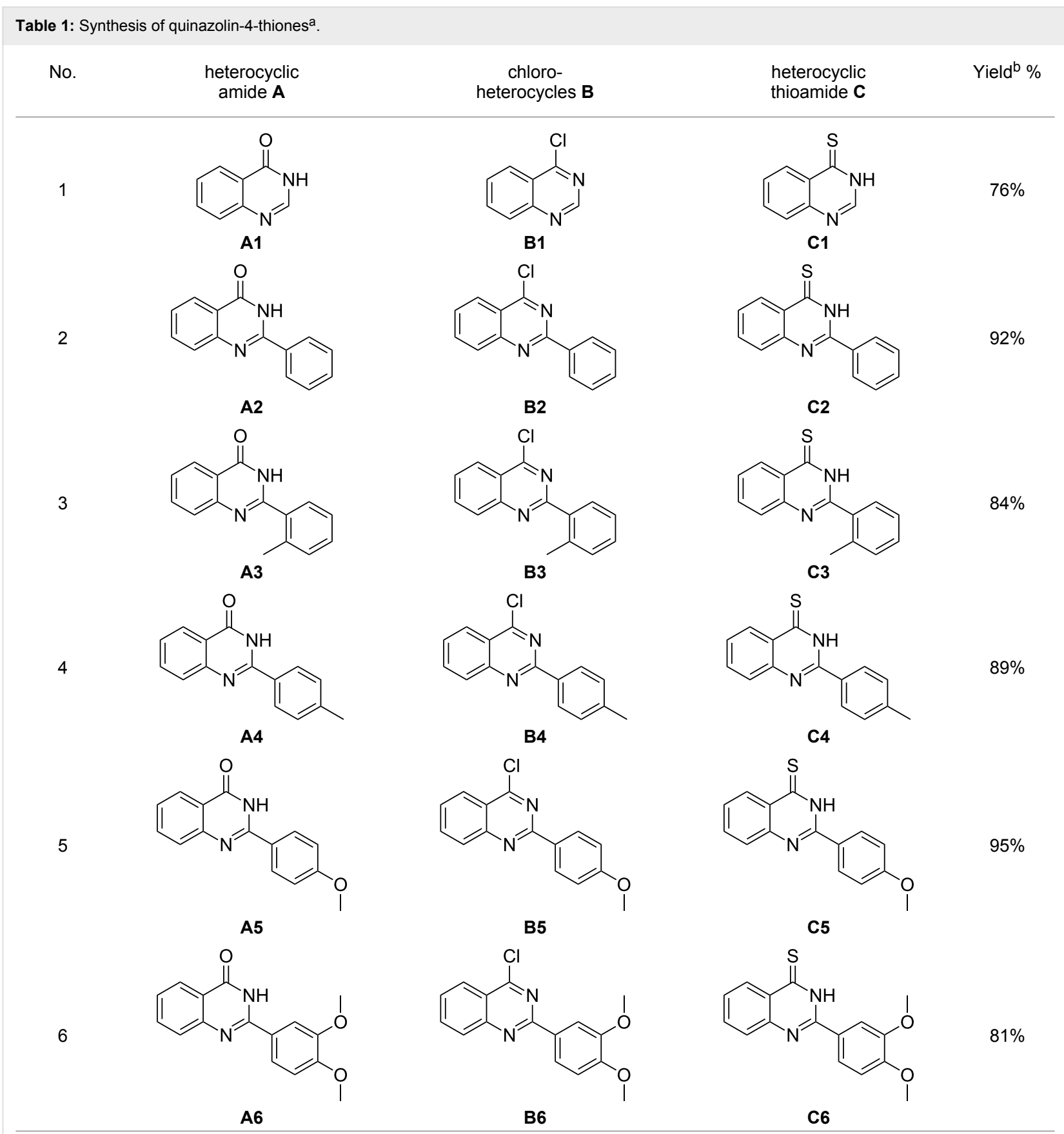

aReaction conditions: chloroheterocycles $(20 \mathrm{mmol})$ and $\mathrm{N}$-cyclohexyl dithiocarbamate cyclohexylammonium salt $(2,20 \mathrm{mmol})$ were heated in $\mathrm{CHCl}_{3}$ $(25 \mathrm{~mL})$ at $61{ }^{\circ} \mathrm{C}$ for $12 \mathrm{~h}$. ${ }^{b}$ Yields refer to isolated pure product of the reaction from $\mathbf{B}$ to $\mathbf{C}$.

The $N$-cyclohexyl dithiocarbamate cyclohexylammonium salt (2) has been found to be an excellent reagent for thiation of heterocyclic amides into thioamides at position 4, Scheme 2, Table 1 and Table 2. We have extended the scope of this thiation process to involve heterocyclic amides at positions 2 and 3 . Thus, methyl 1,2-dihydro-2-oxoquinoline-4-carboxylate (A9) and 3-substituted quinoxalin-2(1H)-ones A10-13 reacted similarly with phosphorous oxychloride to afford the chloro derivatives B9-13 which were subsequently converted into the corresponding thioamides $\mathbf{C 9 - 1 3}$ by the reaction with $\mathrm{N}$-cyclohexyl dithiocarbamate cyclohexylammonium salt (2) in $\mathrm{CHCl}_{3}$ under reflux conditions for $12 \mathrm{~h}$ (Scheme 3, Table 3).

The synthetic procedure for the formation of C1-13 reported herein have the advantage of operational simplicity and availability of both the substrate and the reagents giving a series of 
Table 2: Synthesis of phthalizin-1-thiones $\mathbf{C 7}$ and $\mathbf{C} \mathbf{8}^{\mathrm{a}}$.

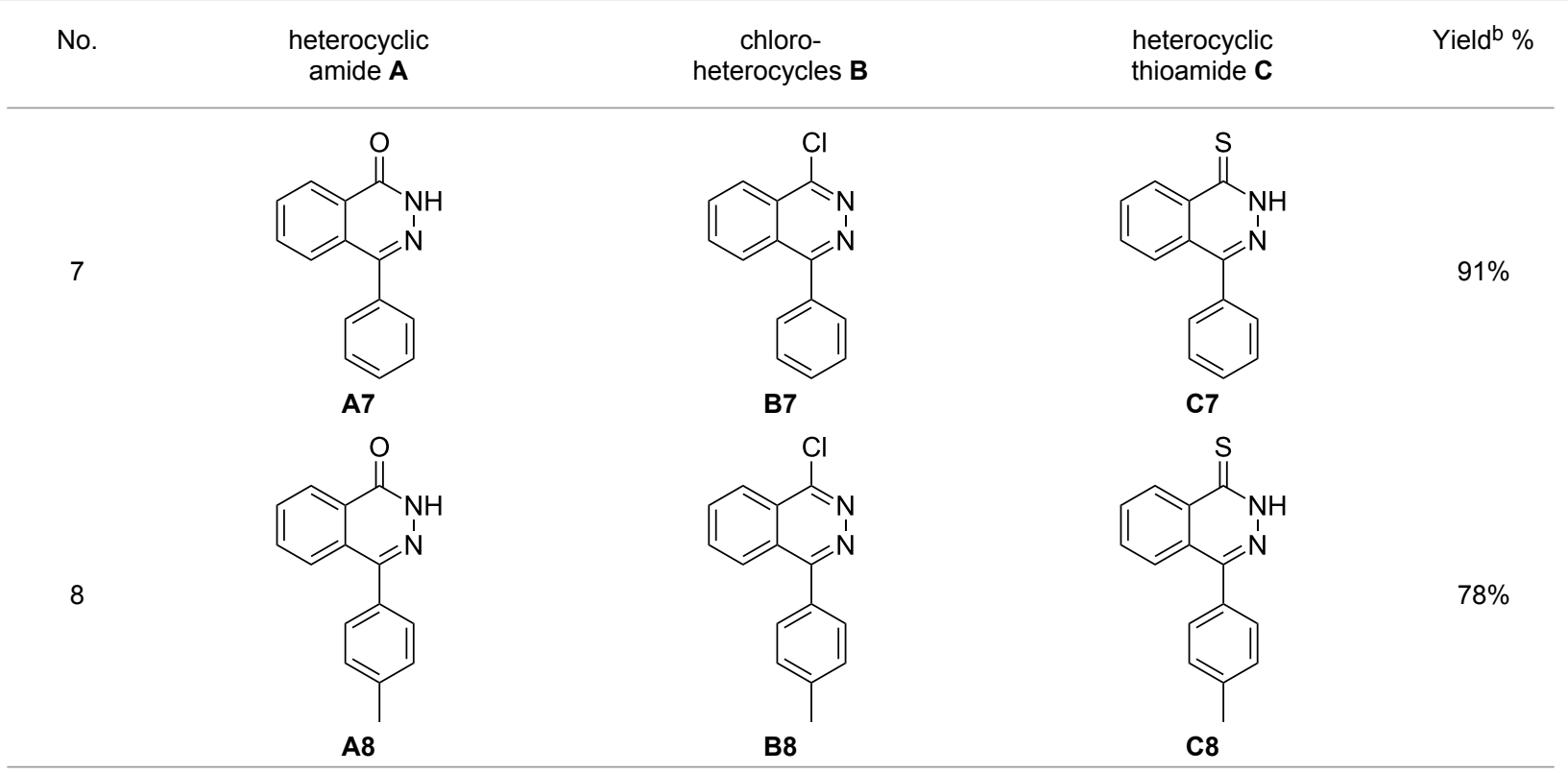

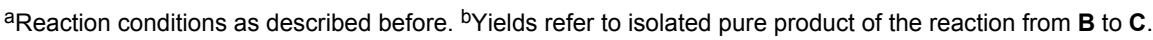

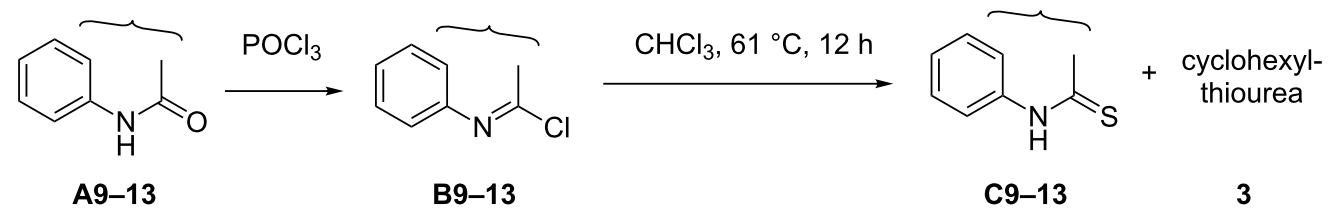

Scheme 3: Thiation of quinoline A9 and quinoxalinone A10-13.

Table 3: Synthesis of quinolin-2-thiones $\mathbf{C 9}$ and quinoxalin-2-thiones $\mathbf{C} 10-\mathbf{C} 13^{\mathrm{a}}$.

No.

$$
\begin{gathered}
\text { heterocyclic } \\
\text { amide A }
\end{gathered}
$$

chloroheterocycles B

heterocyclic thioamide $\mathbf{C}$

Yield $^{b} \%$<smiles>CC(=O)c1cc(=O)[nH]c2ccccc12</smiles>

A9<smiles>CC(=O)c1cc(Cl)nc2ccccc12</smiles>

B9<smiles>CC(=O)c1cc(=S)[nH]c2ccccc12</smiles>

10<smiles>O=c1[nH]c2ccccc2[nH]c1=O</smiles>

A10

11<smiles>Cc1nc2ccccc2[nH]c1=O</smiles><smiles>Clc1nc2ccccc2nc1Cl</smiles>

B10<smiles>Cc1nc2ccccc2nc1Cl</smiles><smiles>S=c1[nH]c2ccccc2[nH]c1=S</smiles>

$69 \%$<smiles>Cc1nc2ccccc2[nH]c1=S</smiles> 
Table 3: Synthesis of quinolin-2-thiones $\mathbf{C 9}$ and quinoxalin-2-thiones $\mathbf{C} 10-\mathbf{C} \mathbf{1 3}^{\mathrm{a}}$. (continued)

12<smiles>Cc1cc2nc(C)c(=O)[nH]c2cc1C</smiles>

A12

13<smiles>O=c1[nH]c2ccccc2nc1-c1ccccc1</smiles><smiles></smiles>

B12<smiles>Clc1nc2ccccc2nc1-c1ccccc1</smiles>

B13<smiles>Cc1cc2nc(C)c(=S)[nH]c2cc1C</smiles>

C12<smiles>S=c1[nH]c2ccccc2nc1-c1ccccc1</smiles>

C13

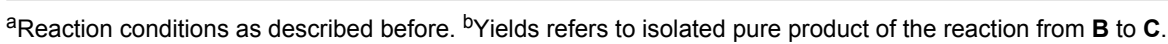

very interesting compounds. This method also was adjusted to involve a one-pot strategy starting from heterocyclic amides A1-13 to directly afford the heterocyclic thioamides C1-13. Thus, 2-phenylquinazolin-4(3H)-one (A2) was heated with phosphorous oxychloride for $2 \mathrm{~h}$. The reaction mixture was evaporated and poured in ice-cold ammonia solution, then extracted with chloroform and dried over sodium sulfate. $\mathrm{N}$-cyclohexyl dithiocarbamate cyclohexylammonium salt (2) was added to the chloroform solution of chloroquinazoline $\mathbf{B 2}$ and heated at $61{ }^{\circ} \mathrm{C}$ for $12 \mathrm{~h}$. The reaction mixture was evapourated and ethanol was added successively to give the desired product $\mathbf{C 2}$.

The structure assignment of the prepared heterocyclic thioamides C1-13 is based on ${ }^{1} \mathrm{H}$ and ${ }^{13} \mathrm{C}$ NMR spectral and physicochemical analyses. The ${ }^{1} \mathrm{H}$ NMR spectrum of 2-(4methoxyphenyl)quinazoline-4(3H)-thione (C5) gave a broad singlet and a singlet signal at $\delta 13.71$ and $3.87 \mathrm{ppm}$, associated with $\mathrm{NH}$ and $\mathrm{OCH}_{3}$ groups, respectively. The significant downfield shift of the NH proton is probably due to intermolecular hydrogen bond interactions of the type $\mathrm{NH} \cdots \mathrm{S}=\mathrm{C}$. All the isolated thioureas C1-13 exhibited similar ${ }^{1} \mathrm{H}$ NMR spectral patterns with the NH protons at similar chemical shifts and they adopt paired thioamide structures (vide infra). The ${ }^{1} \mathrm{H}$ NMR spectrum also shows four doublet and two triplet signals at $\delta 8.60,8.19$, $7.75,7.11,7.88,7.56$, respectively due to eight aromatic protons. The ${ }^{13} \mathrm{C}$ NMR spectrum of $\mathbf{C 5}$ displays signals at $\delta 187.9$ and $56.0 \mathrm{ppm}$ due to $\mathrm{C}=\mathrm{S}$ and $\mathrm{OCH}_{3}$, respectively

A mechanistic rationalization for this interesting rearrangement is given in Scheme 4. The reaction of 4-chloro-2-phenylquinazoline (B2) with $N$-cyclohexyl dithiocarbamate cyclohexylammonium salt (2) in $\mathrm{CHCl}_{3}$ at $61^{\circ} \mathrm{C}$ for $12 \mathrm{~h}$ was principally expected to give 2-phenylquinazolin-4-yl cyclohexylcarbamodithioate (I) and cyclohexylamine hydrochloride. Cyclohexylamine hydrochloride under heating conditions will eliminate an $\mathrm{HCl}$ molecule forming the free cyclohexylamine base.

Cyclohexylamine will further abstract a proton from $\mathbf{I}$ followed by electron delocalization and the overall formation of cyclohexyl isothiocyanate (4) via $\mathrm{C}-\mathrm{S}$ bond cleavage and the formation of quinazoline thiol anion II having a negative charge concerted on the nitrogen atom. The protonated cyclohexylamine in the previous step will transfer this extra proton to II to afford the quinazoline thione $\mathbf{C 2}$. On the other hand the free cyclohexylamine will add to cyclohexyl isothiocyanate (4) to form the thiourea 3. Similar results were obtained by Furumoto [40], and Sun [41] reported the application of cyanuric chloride (2,4,6-trichloro-1,3,5-triazine, TCT) as a desulfurylation reagent in the synthesis of carbodiimides or alkyl isothiocyanates from thioureas under mild conditions.

\section{Conclusion}

Several synthetic procedures related to thiation of heterocyclic amides have been reported to date. The drawback of the existing methods is the use of expensive specific reagents, high temperature, use of strong basic conditions, ultra-dry solvents, bad smell, low yield, difficulties in work-up procedures or from a narrow substrate scope. In this work, we successfully developed a facile and convenient general method for the transformation of heterocyclic amides into heterocyclic thioamides. Generally, in the proposed technique we transformed heterocyclic amides to chloroheterocyclic compounds by the action of phosphorous oxychloride. Subsequently, chloroheterocyclic derivatives reacted with $N$-cyclohexyl dithiocarbamate cyclohexylammonium salt in chloroform at $61{ }^{\circ} \mathrm{C}$ for $12 \mathrm{~h}$ to finally afford the heterocyclic thioamides in excellent yields. Furthermore, this method is advantageous over existing methods in the matter of simplicity of the work-up procedure, higher yield, odorless, lower reaction temperature and finally the availability of both precursors and reagent. 
<smiles>Clc1nc(-c2ccccc2)nc2ccccc12</smiles><smiles>O=C(NC1CCCCC1)C1CCCCC1N[SH](=O)=S</smiles><smiles></smiles>

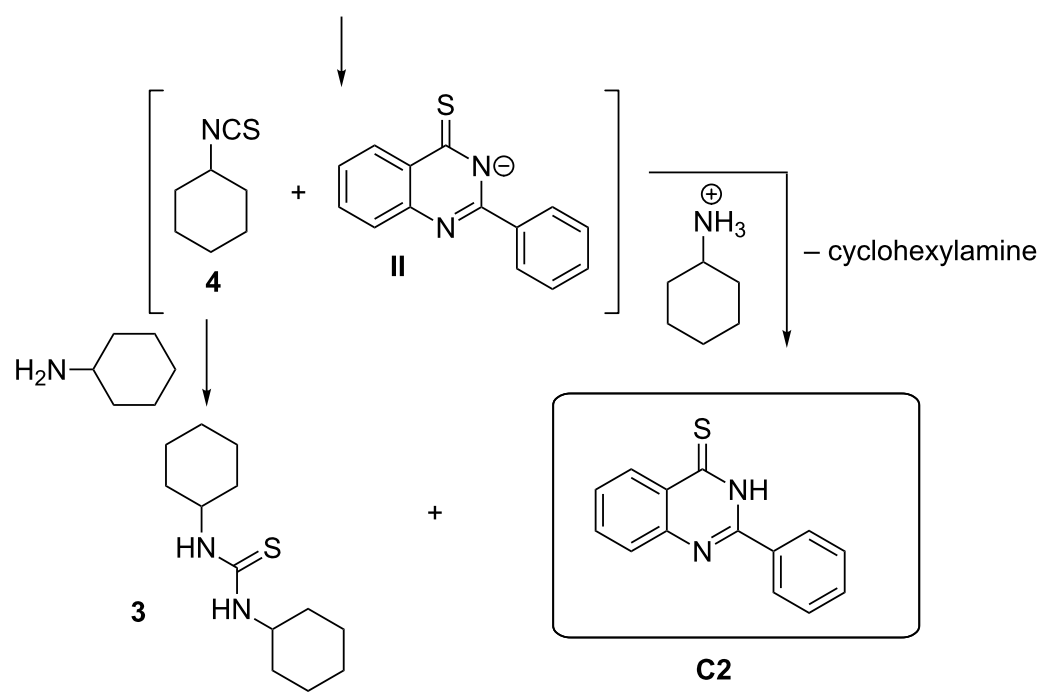

Scheme 4: Rational mechanism of the reaction of 4-chloro-2-phenylquinazoline (B2) to 2-phenylquinazolin-4(3H)-thione.

\section{Experimental}

\section{General procedures}

Solvents were purified and dried by standard procedures. The boiling range of the petroleum ether used was $40-60{ }^{\circ} \mathrm{C}$. Thinlayer chromatography (TLC): silica gel $60 \mathrm{~F}_{254}$ plastic plates (E. Merck, layer thickness $0.2 \mathrm{~mm}$ ) detected by UV absorption. Elemental analyses were performed on a Flash EA-1112 instrument at the Microanalytical laboratory, Faculty of Science, Suez Canal University, Ismailia, Egypt. Melting points were determined on a Büchi 510 melting-point apparatus and the values are uncorrected. ${ }^{1} \mathrm{H}$ and ${ }^{13} \mathrm{C}$ NMR spectra were recorded at $300 \mathrm{MHz}$ and $75.5 \mathrm{MHz}$, respectively (Bruker AC 300) in $\mathrm{CDCl}_{3}$ and DMSO solution with tetramethylsilane as an internal standard. The NMR analyses were performed at the Organic Chemistry Department Masaryk University, Brno, Czech Republic. Compounds A1-13 and B1-13 were obtained by published methods [18-39], and their melting points and ${ }^{1} \mathrm{H}$ and ${ }^{13} \mathrm{C}$ NMR spectra corresponded to those given in the literature.

General method for the preparation of thiating reagent $N$-cyclohexyl dithiocarbamate cyclohexylammonium salt (2). To a mixture of freshly distilled cyclohexylamine
(60 $\mathrm{mmol})$ and water $(50 \mathrm{~mL})$ was added carbon disulfide (21 mmol) dropwise. The reaction mixture was stirred at room temperature for $2 \mathrm{~h}$. The white solid obtained was filtered, washed with water, dried and crystalized from ethanol to provide the pure product. Yield 98\% (ethanol 95\%) white crystals, mp 188-189 ${ }^{\circ} \mathrm{C} ;{ }^{1} \mathrm{H}$ NMR (300 MHz, DMSO- $\left.d_{6}\right) \delta 8.01$ (bs, 3H, 3NH), 4.15-3.95 (m, 1H, CH), 3.05-2.96 (m, 1H, CH), $1.98-0.96\left(20 \mathrm{H}, \mathrm{m}, 10 \mathrm{CH}_{2}\right) ;{ }^{13} \mathrm{C} \mathrm{NMR}\left(75.0 \mathrm{MHz}, \mathrm{DMSO}-d_{6}\right)$ $\delta 212.4(\mathrm{C}=\mathrm{S}), 55.3(\mathrm{CH}), 50.0(\mathrm{CH}), 32.3\left(2 \mathrm{CH}_{2}\right), 30.9$ $\left(2 \mathrm{CH}_{2}\right), 25.8\left(\mathrm{CH}_{2}\right), 25.5\left(2 \mathrm{CH}_{2}\right), 25.1\left(\mathrm{CH}_{2}\right), 24.3\left(2 \mathrm{CH}_{2}\right)$; anal. calcd for $\mathrm{C}_{13} \mathrm{H}_{26} \mathrm{~N}_{2} \mathrm{~S}_{2}$ (274.2): C, 56.56; H, 9.43; N, 10.09; found: C, 56.88; H, 9.55; N, 10.21.

\section{General method for the preparation of hetero- cyclic thioamides}

Method A. To a solution of chloroheterocycles $(2.5 \mathrm{mmol})$ in $\mathrm{CHCl}_{3}(25 \mathrm{~mL})$ was added $(0.69 \mathrm{~g}, 2.5 \mathrm{mmol})$ of $N$-cyclohexyl dithiocarbamate cyclohexylammonium salt. The reaction mixture was refluxed at $61{ }^{\circ} \mathrm{C}$ for $12 \mathrm{~h}$. The reaction mixture was evaporated under reduced pressure and $25 \mathrm{~mL}$ of ethanol was added to the solid residue. The yellowish-orange precipitate was filtered to give the desired product. The crude compounds 
were pure enough for analytical purposes. Purification of products for analysis was achieved by crystallization from the appropriate solvent; chromatographed with the appropriate eluent or by repeated dissolution in $\mathrm{KOH}$ and reprecipitation by acetic acid. The filtrate was evaporated once again and the solid obtained was crystalized from ethanol water to give symmetrical dicyclohexylthiourea (3).

Method B. To a cold solution of heterocyclic amide $(2.5 \mathrm{mmol})$ in $\mathrm{POCl}_{3}(25 \mathrm{~mL})$ was added dimethylaniline $(2.5 \mathrm{mmol})$. The reaction mixture was stirred under reflux $\left(100-105{ }^{\circ} \mathrm{C}\right)$ for $1.5-2 \mathrm{~h}$. The excess $\mathrm{POCl}_{3}$ was removed under reduced pressure. The residue was poured into a mixture of chloroform $(50 \mathrm{~mL})$, ice water $(80 \mathrm{~mL})$ and ammonia $(5 \mathrm{~mL})$. The chloroform layer was separated, dried over $\mathrm{Na}_{2} \mathrm{SO}_{4}$ and filtered. To this chloroform solution of the in situ generated chloroheterocycles was added ( $0.69 \mathrm{~g}, 2.5 \mathrm{mmol})$ of $N$-cyclohexyl dithiocarbamate cyclohexylammonium salt. The reaction mixture was refluxed at $61{ }^{\circ} \mathrm{C}$ for $12 \mathrm{~h}$. The reaction mixture was evaporated under reduced pressure and $25 \mathrm{~mL}$ of ethanol was added to the solid residue. The yellowish-orange precipitate was filtered to give the desired product. The crude compounds were pure enough for analytical purposes. Purification of products for analysis was achieved by crystallization from the appropriate solvent; chromatographed with the appropriate eluent or by repeated dissolution in $\mathrm{KOH}$ and reprecipitation by acetic acid.

Dicyclohexylthiourea (3) [42]: Yield 65\% (ethanol 95\%- $\mathrm{H}_{2} \mathrm{O}$ ) white crystals, mp $180-181{ }^{\circ} \mathrm{C}$; ${ }^{1} \mathrm{H}$ NMR (300 MHz, DMSO$\left.d_{6}\right) \delta 7.05$ (bs, $\left.2 \mathrm{H}, \mathrm{NH}\right), 4.05-3.89(\mathrm{~m}, 2 \mathrm{H}, 2 \mathrm{CH}), 1.87-1.52$ $\left(\mathrm{m}, 10 \mathrm{H}, 5 \mathrm{CH}_{2}\right) 1.29-1.12\left(\mathrm{~m}, 10 \mathrm{H}, 5 \mathrm{CH}_{2}\right) ;{ }^{13} \mathrm{C}$ NMR $(75.0$ MHz, DMSO- $\left.d_{6}\right) \delta 180.5(\mathrm{C}=\mathrm{S}), 51.9(\mathrm{CH}), 32.8\left(2 \mathrm{CH}_{2}\right), 25.7$ $\left(2 \mathrm{CH}_{2}\right), 25.0\left(\mathrm{CH}_{2}\right)$; anal. calcd for $\mathrm{C}_{13} \mathrm{H}_{24} \mathrm{~N}_{2} \mathrm{~S}$ (240.2): $\mathrm{C}$, 64.95; H, 10.06; N, 11.65; found: C, 64.82; H, 10.01; N, 11.46.

Quinazoline-4(3H)-thione (C1) [43]: Yield 76\% $\left(\mathrm{H}_{2} \mathrm{O}\right)$ yellow crystals, mp 320-321 ${ }^{\circ} \mathrm{C}$; ${ }^{1} \mathrm{H}$ NMR (300 MHz, DMSO- $\left.d_{6}\right) \delta$ 13.83 (bs, $1 \mathrm{H}, \mathrm{NH}), 8.55-7.28$ (m, 5H, ArH); ${ }^{13} \mathrm{C}$ NMR $(75.0$ $\left.\mathrm{MHz}, \mathrm{DMSO}-d_{6}\right) \delta 186.2(\mathrm{C}=\mathrm{S}), 144.8$ (C Ar), 144.2 (CHAr), 135.7 (CHAr), 129.7 (CHAr), 129.4 (C Ar), 128.7 (CHAr), 128.5 (CHAr); anal. calcd for $\mathrm{C}_{8} \mathrm{H}_{6} \mathrm{~N}_{2} \mathrm{~S}$ (162.0): C, 59.23; $\mathrm{H}$, 3.73 ; N, 17.27; found: C, 59.17; H, 3.69; N, 17.15.

2-Phenylquinazoline-4(3H)-thione (C2) [44]: Yield 92\% (ethanol 95\%-DMF) yellow crystals, mp $222-223{ }^{\circ} \mathrm{C} ;{ }^{1} \mathrm{H}$ NMR (300 MHz, DMSO- $\left.d_{6}\right) \delta 13.75$ (bs, $\left.1 \mathrm{H}, \mathrm{NH}\right), 8.63$ (d, $J=8.0$ $\mathrm{Hz}, 1 \mathrm{H}, \mathrm{ArH}), 8.17$ (d, J=8.0 Hz, 2H, ArH), 7.93-7.89 (m, 3H, ArH), 7.82-7.57 (m, 3H, ArH); ${ }^{13} \mathrm{C}$ NMR (75.0 MHz, DMSO$\left.d_{6}\right) \delta 188.5(\mathrm{C}=\mathrm{S}), 152.1$ (C Ar), 144.8 (C Ar), 135.8 (CHAr), 132.8 (C Ar), 131.9 (CHAr), 129.8 (CHAr), 128.9 (CHAr), 128.6 (CHAr), 128.4 (CHAr), 128.1 (C Ar); anal. calcd for
$\mathrm{C}_{14} \mathrm{H}_{10} \mathrm{~N}_{2} \mathrm{~S}$ (238.1): C, 70.56; H, 4.23; N, 11.76; found: $\mathrm{C}$, 70.48; H, 4.16; N, 11.49 .

2-o-Tolylquinazoline-4(3H)-thione (C3) [45]: Yield 84\% (ethanol 95\%-DMF) yellow crystals, mp $183-184{ }^{\circ} \mathrm{C}$; ${ }^{1} \mathrm{H}$ NMR $\left(300 \mathrm{MHz}, \mathrm{DMSO}-d_{6}\right) \delta 13.97$ (bs, $\left.1 \mathrm{H}, \mathrm{NH}\right), 8.65$ (d, $J=8.0$ $\mathrm{Hz}, 1 \mathrm{H}, \mathrm{ArH}), 7.96$ (t, $J=8.0 \mathrm{~Hz}, 1 \mathrm{H}, \mathrm{ArH}), 7.75$ (d, $J=8.0$ $\mathrm{Hz}, 1 \mathrm{H}, \mathrm{ArH}), 7.66-7.35$ (m, 5H, ArH), $2.39\left(\mathrm{~s}, 3 \mathrm{H}, \mathrm{CH}_{3}\right) ;{ }^{13} \mathrm{C}$ NMR (75.0 MHz, DMSO-d $\left.{ }_{6}\right) \delta 187.7(\mathrm{C}=\mathrm{S}), 155.5$ (C Ar), 144.7 (C Ar), 136.8 (C Ar), 135.8 (CHAr), 134.0 (CHAr), 130.9 (C Ar), 130.6 (CHAr), 130.0 (CHAr), 129.7 (CHAr), 128.6 (CHAr), 128.0 (CHAr), 126.1 (C Ar), $19.9\left(\mathrm{CH}_{3}\right)$; anal. calcd for $\mathrm{C}_{15} \mathrm{H}_{12} \mathrm{~N}_{2} \mathrm{~S}$ (252.1): C, 71.40; H, 4.79; N, 11.10; found: $\mathrm{C}$, $71.21 ; \mathrm{H}, 4.65 ; \mathrm{N}, 10.94$.

2-p-Tolylquinazoline-4(3H)-thione (C4) [46]: Yield 89\% (ethanol 95\%-DMF) yellow crystals, mp $218-219{ }^{\circ} \mathrm{C}$; ${ }^{1} \mathrm{H}$ NMR $\left(300 \mathrm{MHz}, \mathrm{DMSO}-d_{6}\right) \delta 13.78$ (bs, $\left.1 \mathrm{H}, \mathrm{NH}\right), 8.62$ (d, $J=8.0$ $\mathrm{Hz}, 1 \mathrm{H}, \mathrm{ArH}), 8.10$ (d, $J=8.0 \mathrm{~Hz}, 2 \mathrm{H}, \mathrm{ArH}), 7.93-7.76$ (m, 2H, $\operatorname{ArH}), 7.58$ (t, $J=8.0 \mathrm{~Hz}, 1 \mathrm{H}, \mathrm{ArH}), 7.37$ (d, $J=8.0 \mathrm{~Hz}, 2 \mathrm{H}$, $\mathrm{ArH}), 2.41\left(\mathrm{~s}, 3 \mathrm{H}, \mathrm{CH}_{3}\right) ;{ }^{13} \mathrm{C} \mathrm{NMR}\left(75.0 \mathrm{MHz}, \mathrm{DMSO}-d_{6}\right)$ $\delta 187.9(\mathrm{C}=\mathrm{S}), 151.9$ (C Ar), 149.3 (C Ar), 142.1 (C Ar), 135.9 (CHAr), 130.4 (C Ar), 129.8 (CHAr), 129.7 (CHAr), 129.6 (CHAr), 128.8 (CHAr), 126.3 (CHAr), 128.0 (CHAr), 126.4 (C Ar), $21.5\left(\mathrm{CH}_{3}\right)$; anal. calcd for $\mathrm{C}_{15} \mathrm{H}_{12} \mathrm{~N}_{2} \mathrm{~S}$ (252.1): C, 71.40; H, 4.79; N, 11.10; found: C, 71.28; H, 4.61; N, 11.84 .

The yield, ${ }^{1} \mathrm{H},{ }^{13} \mathrm{C}$ NMR spectral data and physicochemical analysis of other prepared thioamides (C5-C13) are presented in Supporting Information File 1.

\section{Supporting Information}

\section{Supporting Information File 1}

Additional experimental and analytical data.

[http://www.beilstein-journals.org/bjoc/content/ supplementary/1860-5397-13-20-S1.pdf]

\section{Acknowledgements}

We would like to thank the Department of Organic Chemistry, Faculty of Science, Masaryk University, Brno, Czech Republic and the Ministry of high education Egypt for funding this research proposal. We would like to thank Dr. Hewayda El-Ghawalby for technical support.

\section{References}

1. Ozturk, T.; Ertas, E.; Mert, O. Chem. Rev. 2007, 107, 5210. doi:10.1021/cr040650b

2. Ozturk, T.; Ertas, E.; Mert, O. Chem. Rev. 2010, 110, 3419. doi: $10.1021 /$ cr900243d 
3. Curphey, T. J. J. Org. Chem. 2002, 67, 6461. doi:10.1021/jo0256742

4. Libermann, R. Bull. Soc. Chim. Fr. 1959, 1793.

5. Leonard, N. J.; Curtin, D. Y. J. Org. Chem. 1946, 11, 349. doi:10.1021/jo01174a007

6. Armstrong, R. T. Vulcanization accelerators. U.S. Patent US2382769 Aug 14, 1945

7. Morrison, D. C.; Furst, A. J. Org. Chem. 1956, 21, 470. doi:10.1021/jo01110a026

8. Asano, K. Yakugaku Zasshi 1958, 78, 729.

9. El-Hawash, S. A. M.; Abdel Wahab, A. E. Arch. Pharm. 2006, 339, 437. doi:10.1002/ardp.200600012

10. Fathalla, W.; Čajan, M.; Pazdera, P. Molecules 2000, 5, 1210. doi:10.3390/51201210

11. Fathalla, W.; Čajan, M.; Pazdera, P. Molecules 2001, 6, 557. doi:10.3390/60600557

12. Fathalla, W.; Pazdera, P.; Marek, J. J. Heterocycl. Chem. 2002, 39, 1139. doi:10.1002/jhet.5570390605

13. Fathalla, W.; Marek, J.; Pazdera, P. J. Sulfur Chem. 2008, $29,31$. doi:10.1080/17415990701759685

14. Fathalla, W. ARKIVOC 2008, xii, 245

15. Ali, I. A. I.; Fathalla, W. Heteroat. Chem. 2006, 17, 280. doi:10.1002/hc.20203

16. Fathalla, W.; EI Rayes, S.; Ali, I. A. I. ARKIVOC 2008, xiii, 179.

17. Fathalla, W. Chem. Heterocycl. Compd. 2015, 51, 67. doi:10.1007/s10593-015-1661-1

18. Yamamoto, Y. Methods of molecular hetarenes and related ring systems; Science of Synthesis: Houben-Weyl, Vol. 16; 2003; pp 726 ff.

19. Sundaram, R.; Yuvaraj, E.; Babu, G. Indian J. Chem., Sect. B: Org. Chem. Incl. Med. Chem. 1999, 38, 905.

20. Lee, E. S.; Son, J. K.; Na, Y. H.; Jahng, Y. Heterocycl. Commun. 2004, 10, 325. doi:10.1515/HC.2004.10.4-5.325

21. Okada, K.; Sakuma, H.; Inoue, S. Chem. Lett. 1979, 8, 131. doi:10.1246/cl.1979.131

22. Chawla, H. M.; Gupta, T. J. Inclusion Phenom. Macrocyclic Chem. 2015, 81, 49. doi:10.1007/s10847-014-0432-4

23. Derbala, H. A. Y. Indian J. Chem., Sect. B: Org. Chem. Incl. Med. Chem. 1994, 33, 779.

24. Ismail, M. F.; Kandile, N. G. Acta Chim. Hung. 1991, 128, 251.

25. Ajani, O. O.; Obafemi, C. A.; Ikpo, C. O.; Ogunniran, K. O.; Nwinyi, O. C. Chem. Heterocycl. Compd. 2009, 45, 1370. doi:10.1007/s10593-010-0435-z

26. Noolvi, M. N.; Patel, H. M.; Bhardwaj, V.; Chauhan, A. Eur. J. Med. Chem. 2011, 46, 2327. doi:10.1016/j.ejmech.2011.03.015

27. Mahesh, R.; Dhar, A. K.; Sasank, T. V. N. V. T.; Thirunavukkarasu, S.; Devadoss, T. Chin. Chem. Lett. 2011, 22, 389. doi:10.1016/j.cclet.2010.11.002

28. Elhelby, A. A.; Ayyad, R. R.; Zayed, M. F. Arzneim. Forsch. 2011, 61, 379. doi:10.1055/s-0031-1296214

29. Shi, L.; Wu, T.-T.; Wang, Z.; Xu, J.-Y.; Xu, Y.-G. Bioorg. Med. Chem. 2014, 22, 4735. doi:10.1016/j.bmc.2014.07.008

30. Marvania, B.; Lee, P.-C.; Chaniyara, R.; Dong, H.; Suman, S.; Kakadiya, R.; Chou, T.-C.; Lee, T.-C.; Shah, A.; Su, T.-L. Bioorg. Med. Chem. 2011, 19, 1987. doi:10.1016/j.bmc.2011.01.055

31. Aly, A. A. J. Chin. Chem. Soc. 2007, 54, 437. doi:10.1002/jccs.200700061

32. Browner, M.; Clark, D.; Cushing, T.; Hao, X.; Hawley, R.; He, X.; Jaen, J.; Lebadie, S.; Smith, M.-L.; Talmas, F.; Walker, N.; Labelle, M. Antiinflammation agents. U.S. Pat. Appl. US 20020161004 A1, Oct 31, 2002.
33. Rival, Y.; Hoffmann, R.; Didier, B.; Rybaltchenko, V.; Bourguignon, J.; Wermuth, C. G. J. Med. Chem. 1998, 41, 311. doi:10.1021/jm9705418

34. Hemdan, M. M.; Taha, S. M.; Gabr, A. M.; Elkady, M. Y. J. Chem. Res. 2010, 34, 102. doi:10.3184/030823410X12658886079090

35. Galal, S. A.; Abdelsamie, A. S.; Tokuda, H.; Suzuki, N.; Lida, A.; ElHefnawi, M. M.; Ramadan, R. A.; Atta, M. H. E.; El Diwani, H. I. Eur. J. Med. Chem. 2011, 46, 327. doi:10.1016/j.ejmech.2010.11.022

36. Da Silva Miranda, F.; Signori, A. M.; Vicente, J.; De Souza, B.; Priebe, J. P.; Szpoganicz, B.; Gonçalves, N. S.; Neves, A. Tetrahedron 2008, 64, 5410. doi:10.1016/j.tet.2008.02.097

37. Aggarwal, R.; Masan, E.; Sumran, G. Synth. Commun. 2013, 43, 1842. doi:10.1080/00397911.2012.674168

38. Wagle, S.; Adhikari, A. V.; Kumari, N. S. Eur. J. Med. Chem. 2009, 44, 1135. doi:10.1016/j.ejmech.2008.06.006

39. Koshel, N. G.; Kovalev, E. G.; Postovskii, I. Ya. Chem. Heterocycl. Compd. 1970, 6, 791. doi:10.1007/BF00470545

40. Furumoto, S. Nippon Kagaku Zasshi 1971, 92, 1005. doi:10.1246/nikkashi1948.92.1005

41. Sun, N.; Li, B.; Shao, J.; Mo, W.; Hu, B.; Shen, Z.; Hu, X. Beilstein J. Org. Chem. 2012, 8, 61. doi:10.3762/bjoc.8.6

42. Ramadas, K.; Janarthanan, N.; Velmathi, S. Synth. Commun. 1997, 27, 2255. doi:10.1080/00397919708003379

43. Sánchez, A. I.; Martinez-Barrasa, V.; Burgos, C.; Vaquero, J. J.; Alvarez-Builla, J.; Terricabras, E.; Segarra, V. Bioorg. Med. Chem. 2013, 21, 2370. doi:10.1016/j.bmc.2013.01.067

44. Lee, N. K.; Lee, J. W.; Lee, S.; Im, G.-J.; Han, H. Y.; Kim, T. K.; Kwak, W.-j.; Kim, S. W.; Ha, J.; Kim, E. K.; Lee, J. K.; Yoo, C. Y.; Lee, D. Y. Quinazoline derivatives for the treatment and prevention of diabetes and obesity. U.S. Pat. Appl. US20080207614 A1, Aug 28, 2008.

45. Legrand, L. Bull. Soc. Chim. Fr. 1961, 620.

46. Hanusek, J.; Hejtmánková, L.; Kubicová, L.; Sedlák, M. Molecules 2001, 6, 323. doi:10.3390/60400323

\section{License and Terms}

This is an Open Access article under the terms of the Creative Commons Attribution License (http://creativecommons.org/licenses/by/4.0), which permits unrestricted use, distribution, and reproduction in any medium, provided the original work is properly cited.

The license is subject to the Beilstein Journal of Organic Chemistry terms and conditions:

(http://www.beilstein-journals.org/bjoc)

The definitive version of this article is the electronic one which can be found at: $\underline{\text { doi: } 10.3762 / \text { bjoc. } 13.20}$ 